DOI: 10.1515/auseur-2017-0011

\title{
Between the Word of the Law and Practice: a Case of the Hungarian Speakers in Serbia ${ }^{1}$
}

\author{
Marija MANDIĆ \\ Humboldt University of Berlin, Institute for Slavic Studies \\ e-mail: marija.mandic@hu-berlin.de \\ Sandra BULJANOVIĆ SIMONOVIĆ \\ University of Belgrade, Philological Faculty \\ Department of Hungarian Language and Literature \\ e-mail: sandra.buljanovic@gmail.com
}

\begin{abstract}
The paper initially presents the Serbian legislative framework relevant to the use of minority languages. The ethnolinguistic vitality of the Hungarian-speaking population in Serbia is then analysed, particularly in the Serbian province of Vojvodina. The paper then focuses upon the sociolinguistic survey of Hungarian language use in Belgrade. The emphasis is placed upon the survey responses related to the awareness of language rights among the Hungarian speakers.
\end{abstract}

Keywords: language rights, Serbia, Hungarian minority, Vojvodina, Belgrade, sociolinguistic survey

\section{Language Rights in Serbia}

The Constitution of the Republic of Serbia, as the fundamental legislative document, was adopted by referendum in 2006. The Serbian language and Cyrillic script were thus proclaimed official in the state (CONST: Article 10). The rights of persons belonging to national minorities are regulated in the Constitution's third section (CONST: articles 75-81). In the sphere of language rights, national minorities are entitled to the official use of their languages and scripts (CONST: Article 75/3). Language rights are explicitly defined in Article 79 dedicated to 'Right to preservation of specificity'. Persons belonging to national minorities are ensured the right to use their symbols in public places, have proceedings

1 The article is a result of the Language, Folklore, Migrations in the Balkans project (no 178010) funded by the Ministry of Science of the Republic of Serbia. Marija Mandić is supported by Humboldt Research Fellowship for postdoctoral researchers 2016-2018 at the Institute for Slavic Studies, Humboldt University, Berlin. 
conducted in their native languages before state bodies; they are also guaranteed the right to education in their native languages in state institutions, to use their name and family name in native language in official personal documents, to write traditional local names, names of streets and toponyms in native languages. In areas where they constitute a significant majority of the population, they are also afforded the right to complete, timely, and objective information in their native language as well as to establish their own mass media. The requirements which must be met for persons belonging to minority groups are regulated in detail in special laws.

The Law on Official Use of Languages and Alphabets was passed by the Parliament of Republic of Serbia in 2005 and modified in 2010 (cf. The Law 2010). Minority language rights are regulated in its third section: The Official Use of Minority Languages and Scripts. According to the 2010 Law, if the proportion of minority members in a local municipality, according to the last Population Census, reaches $15 \%$ percent or more, then the minority is entitled to use its native language and script as an official language in local self-government, alongside Serbian (The Law 2010: Article 11). ${ }^{2}$ If the number of minority members reaches at least $2 \%$ of Serbia's total population, they are entitled to communicate with state officials in their native language and have a right to get official documents in their native language. ${ }^{3}$ In municipalities in which a minority language is not in official use, a member of a national minority has the right to use their native language and script in legal proceedings and to demand that all legal documents which are related to him/her personally are written in his/her native language and script (The Law 2010: Article 16).

In addition to the aforementioned laws, Serbia has also ratified many international documents and agreements that regulate the use of minority and regional languages. The European Charter for Regional or Minority Languages (ECRML) was ratified in 2006, when Serbia took over obligations for the following languages: Albanian, Bosnian, Bulgarian, Hungarian, Romani, Romanian, Ruthenian, Slovak, Ukrainian, and Croatian (The Ratification of ECRML: Article 3). In 2003, Hungary and Serbia and Montenegro concluded a bilateral accord on the mutual protection of their respective national minorities. ${ }^{4}$

2 The official use of minority languages means that the language can be used in local municipality administration, in front of civil court, in communication between local officials and citizens, in personal documents, in election procedures. Minority members' reaching at least $15 \%$ of the total population within a local municipality also entitles them to write in their native language and script administrative names of the state institutions, names of streets, settlements and their parts (The Law 2010: Article 11).

3 If the number of minority members does not exceed $2 \%$ of Serbia's population, they are entitled to exercise their language rights via the local municipalities, which should cover all the translation expenses regarding communication between minority members and state officials (The Law 2010: Article 11).

4 Agreement between the Republic of Hungary and Serbia and Montenegro on the Protection of 
The Serbian northern province of Vojvodina similarly adopted The Statute of the Autonomous Province of Vojvodina in 2009, in which 10 national communities were recognized with full equality and collective rights under the law; these are: Serbs, Hungarians, Slovaks, Croats, Bunyevs, Montenegrins, Romanians, Roma, Ruthenians, and Macedonians. ${ }^{5}$ The Statute of Vojvodina recognizes six official regional languages, which are used in the provincial government and the official domain: Serbian, Hungarian, Slovak, Romanian, Croatian, and Ruthenian. ${ }^{6}$ In a nutshell, Serbia - and especially its region, Vojvodina - can boast about liberal and advanced legislation on minority protection and language rights.

\section{Hungarian Minority in Serbia: Demography, Language, Institutional Support}

Giles, Bourhis, and Taylor employed the analytical framework of ethnolinguistic vitality to determine the social and psychological factors influencing the vitality of an ethnic group (1977: 308). These authors identified three specific types of variables which seem to affect group vitality, as illustrated below in Chart 1.7

This concept seems adequate for grasping the complex picture of the Hungarian minority in Serbia. According to the demographic indicators, such as birth and emigration rate, and status indicators, such as educational and economic level, Hungarians can be viewed as a community with low vitality. Yet, according to the historical and language status and institutional support, they seem to constitute a vital community. In the following sections, we shall analyse the Hungarian minority with regard to demography (2.1), the status of minority and its language (2.2), and minority institutional support (2.3).

Rights of the Hungarian Minority Living in Serbia and Montenegro and the Serbian Minority Living in the Republic of Hungary, signed on 21 October 2003 (Ratification of Agreement 2004).

$5 \quad$ Article 6 reads as follows: 'Within the scope of its rights and responsibilities, the AP Vojvodina shall contribute to the exercise of a full equality, guaranteed under the Constitution, of Hungarians, Slovaks, Croats, Montenegrins, Romanians, Roma, Bunjevac, Ruthenians, Macedonians and persons belonging to other numerically smaller national minorities - national communities living in its territory and the Serbian people' (STATUTE VOJ: Article 6).

6 Article 24 reads as follows: 'In addition to Serbian language and Cyrillic script, Hungarian, Slovak, Croatian, Romanian and Ruthenian languages and their scripts shall be in official use in authorities of the AP Vojvodina, in conformity with the law. Within the scope of their competences, authorities of the AP Vojvodina shall undertake the measures to ensure a consistent exercise of the official use of languages and scripts of national minorities - national communities stipulated by the law' (STATUTE VOJ: Article 24).

$7 \quad$ Although this analytical framework proved fruitful for sociolinguistics (cf. Vučković 2004; Petrović 2009; Ilić [Mandić] 2014), Petrović (op. cit. 45) points out that it may lead to a simplistic typology of ethnolinguistic groups. 


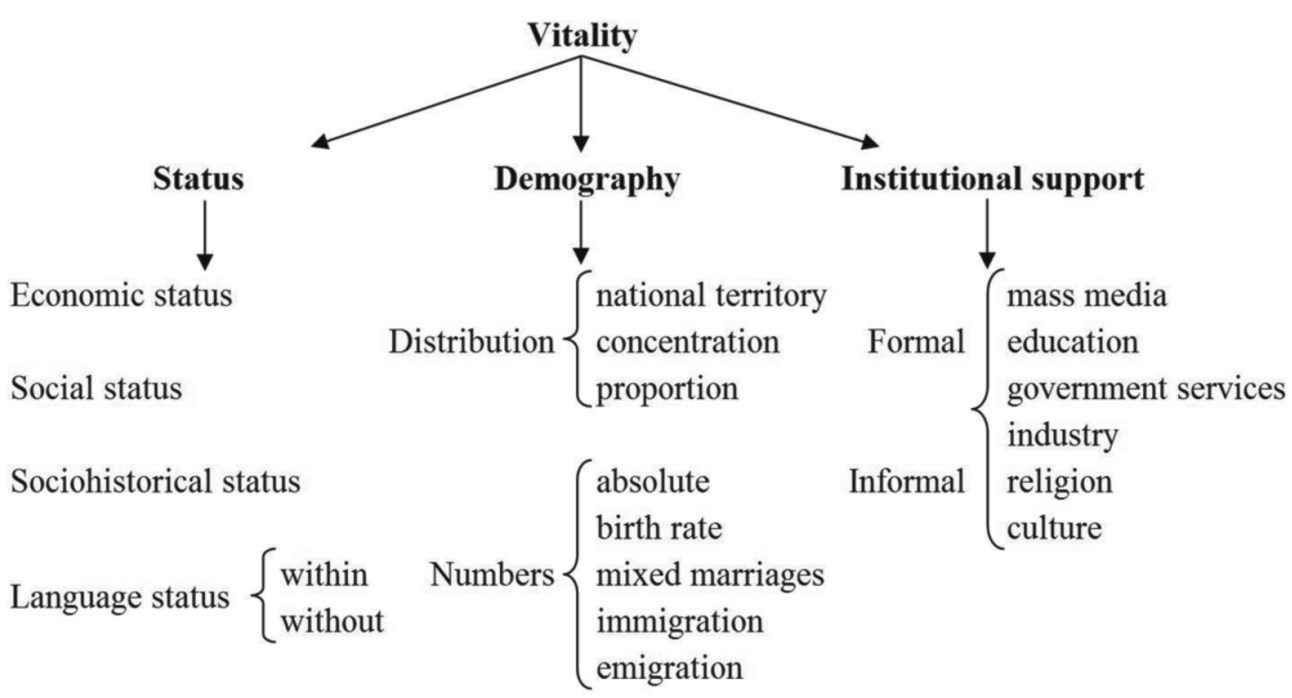

Chart 1. Taxonomy of the structural variables affecting ethnolinguistic vitality (Giles, Bourhis, Taylor 1977: 309)

\subsection{Demography}

Almost the entire Serbian Hungarian population (98-99\%) lives in the northern Serbian province of Vojvodina (in Hungarian: Vajdaság), which has an autonomous status. Vojvodina has traditionally been a multiethnic and multilingual region - at present, out of 45 municipalities, 41 are multiethnic (Beretka 2014: 251). ${ }^{8}$ However, in Vojvodina, two ethnic communities are the most numerous - Serbian (67\%) and Hungarian (13\%) (Đurić et al. 2014: 107). Practically, two-thirds of the Hungarians are concentrated in the northern part of Vojvodina, where they make up the absolute or relative majority in eight municipalities. ${ }^{9}$ In that way, Serbian Hungarians form more or less a compact territorial continuum with the neighbouring Hungary, which has had an ambivalent influence upon their ethnolinguistic vitality. On the one hand, in the northern and western Hungarian settlements, most of the everyday communication takes place in Hungarian

8 According to the Serbian law, 'in order to consider a municipality to be multiethnic, $5 \%$ of the total number of its inhabitants should belong to a national minority, or the number of all national minority members in total should be at least $10 \%$ of the total number of inhabitants' (Gojković 2009: 4).

9 The municipalities with an absolute and relative Hungarian majority are: Kanjiža (in Hungarian: Kanizsa, or Magyarkanizsa with 85.1\% Hungarians), Senta (in Hungarian: Zenta, 79.1\%), Ada (in Hungarian: Ada, 75\%), Bačka Topola (in Hungarian: Topolya, 57.9\%), Mali Iđoš (in Hungarian: Kishegyes, 53.9\%), Čoka (in Hungarian: Csóka, 49.7\%), Bečej (in Hungarian: Óbecse, 46.3\%), and Subotica (in Hungarian: Szabadka, 35.6) (cf. Đurić et al. 2014: 111). 
language within the 'Hungarian world' (Brubaker et al. 2006: 266), while social interactions with non-Hungarian speakers are less frequent and marked by social distance (Rácz 2014). On the other hand, the closeness of the Hungarian border reduces the necessity and willingness of the Serbian Hungarians to integrate into the Serbian society and fosters their emigration from Serbia to their kinstate of Hungary, which is an EU Member State, unlike Serbia. This presents the possibility to move further on to other western lands.

According to the last Serbian census held in 2011, 253,899 respondents claimed Hungarian ethnicity, which makes $3.53 \%$ of the country's total population; 243,146 gave Hungarian as their 'mother tongue', which amounts to $3.4 \%$ of the population (2011 census: 22, 55, 63, 71-73; Đurić et al. 2014: 102). ${ }^{10}$ Their cultural and political centre is the town of Subotica (in Hungarian: Szabadka), in which there lives every fifth Hungarian in Serbia $(50,469)$. Likewise, Hungarians are concentrated in the following cities: Zrenjanin (in Hungarian: Nagybecskerek) $(12,350)$, Novi Sad (in Hungarian: Újvidék) $(13,272)$, and Sombor (in Hungarian: Zombor, and before Czoborszentmihály) (9,874) (Đurić et al. 2014: 111). The majority of Hungarians in Serbia are Roman Catholics by faith (88.35\%), while a smaller group is Protestant (mostly Calvinist) (6.25\%) (Đurić et al. 2014: 192).

Although according to the last, 2011 census, Hungarians are the biggest minority in Serbia, the population decline of the Serbian Hungarians over the last five decades appears to be severe, as illustrated below in Table 1.

Table 1. The number of ethnic Hungarians and the total population of Serbia according to the population censuses of 1948-2011 (Durić et al. 2014: 98-99, 152)11

\begin{tabular}{lccc}
\hline Year & Hungarians in Serbia & Hungarian native language ${ }^{11}$ & $\begin{array}{c}\text { Proportion of Hungarians in } \\
\text { Serbia (\%) }\end{array}$ \\
\hline 1948 & 433,701 & $/$ & 6.64 \\
\hline 1953 & 441,907 & 442,423 & 6.33 \\
\hline 1961 & 449,587 & 449,432 & 5.88 \\
\hline 1971 & 430,314 & 430,621 & 5.09 \\
\hline 1980 & 390,468 & 374,639 & 4.19 \\
\hline 1991 & 343,800 & 348,320 & 4.39 \\
\hline 2002 & 293,299 & 286,508 & 3.91 \\
\hline 2011 & 253,899 & 243,146 & 3.53 \\
\hline
\end{tabular}

10 The legal instructions given to the enumerators said that, according to the Serbian Constitution (CONST 2006), citizens were not obliged to declare themselves in terms of their religion or ethnicity. The 2011 census allowed responses with double declaration of the ethnicity (Serb-Hungarian, Macedonian-Serb, etc.) for the first time. As regards religion, it is not clear whether it refers to active or traditional believers, that is the religion their parents or the family belonged to through generations. In the Serbian censuses, 'mother tongue meant the language which a person learned to speak in its [their] earliest childhood, that is, the language the person considers as its [their] mother tongue if several languages are spoken at the household' (Population Census 2011: 12, 14).

11 Data on mother tongue were not collected in the 1948 census (Đurić et al. 2014: 149) 
The critical demographic trend of the Hungarian population has been evident since the 1960s, and in the past five decades the Hungarian population in Serbia has decreased by nearly half. It needs to be mentioned though that a population decline has been a characteristic of almost all communities in Serbia - both minority and majority - for the past two decades. The only exceptions to this demographic trend are the Roma and Bosniaks, who are on the demographic rise (Đurić et al. 2014: 80, 103-104). The reasons for the drop in population in Serbia are the results of the long-standing harsh economic crisis, low birth rate, and high immigration rate. Regarding minorities, assimilation proves to be a consistent source of population decline (Id.: 182). The demographic shrinkage among Hungarians is especially worrying since it began already in the 1960s, a period in Yugoslavia marked by economic and social prosperity.

According to the 2011 census, the birth rate among Hungarians is below the national average (1.96\%), and it is approximately $1.80 \%$; the average age in Serbia is 42.2 years, whereas among Hungarians it is 45 years (Đurić et al. 2014: 121, 130). The emigration rate of the Hungarians from Serbia is also above the national average (Id.: 182), and it has increased substantially since the adoption of the amendment of the Hungarian Citizenship Act (2010). This act entitled individuals who were Hungarians by way of ancestry or ethnicity to Hungarian citizenship so long as they could prove knowledge of the Hungarian language. These individuals have been able to apply for naturalization and Hungarian citizenship on preferential terms since 1 January 2011. In that way, Hungarian citizenship was easy to attain for Hungarians living outside of Hungary. This policy, however, created many controversies, counter-measures, and resistance, especially in Slovakia and Romania (Csergő, Goldgeier 2013: 109-110; Arraiza 2013; Blokker, Kovács 2013). In Serbia, it was mostly seen as an opportunity to get a passport to a country belonging to the European Union. Thus, it has been taken as an advantage not only by Hungarians but also by many Serbs and people stemming from mixed marriages, who fulfil the Hungarian citizenship requirements.

\subsection{Status}

The Hungarian presence in the province of Vojvodina dates back to the $9^{\text {th }}$ century, to the establishment of the Hungarian Kingdom (1000-1946). For centuries, Hungarians had full or limited territorial sovereignty in the region. This historical legacy gave shape to the national and historical awareness among the Hungarians in Serbia, which reinforced a feeling of belonging to comparatively more prestigious culture than the Serbs (Rácz 2017: 190, Rokai et al. 2002).

According to the last, 2011 census, however, the educational attainment of Hungarians is lower than the Serbian national average: $44.47 \%$ of Hungarians have elementary school either with four (28.85\%) or with eight classes (28.85), 
and almost the same number of them $-45.19 \%$ - have secondary education, while 9.22\% have college or university degree (Đurić et al. 2014: 135). The economic activity of Hungarians is also slightly below a very poor national average: only one third them is employed $(30.59 \%)$, two-thirds are economically inactive (retired, renters, children, pupils, students, housewives/men, others) (61\%), and the others are unemployed (8.21\%), (Id.: 139).

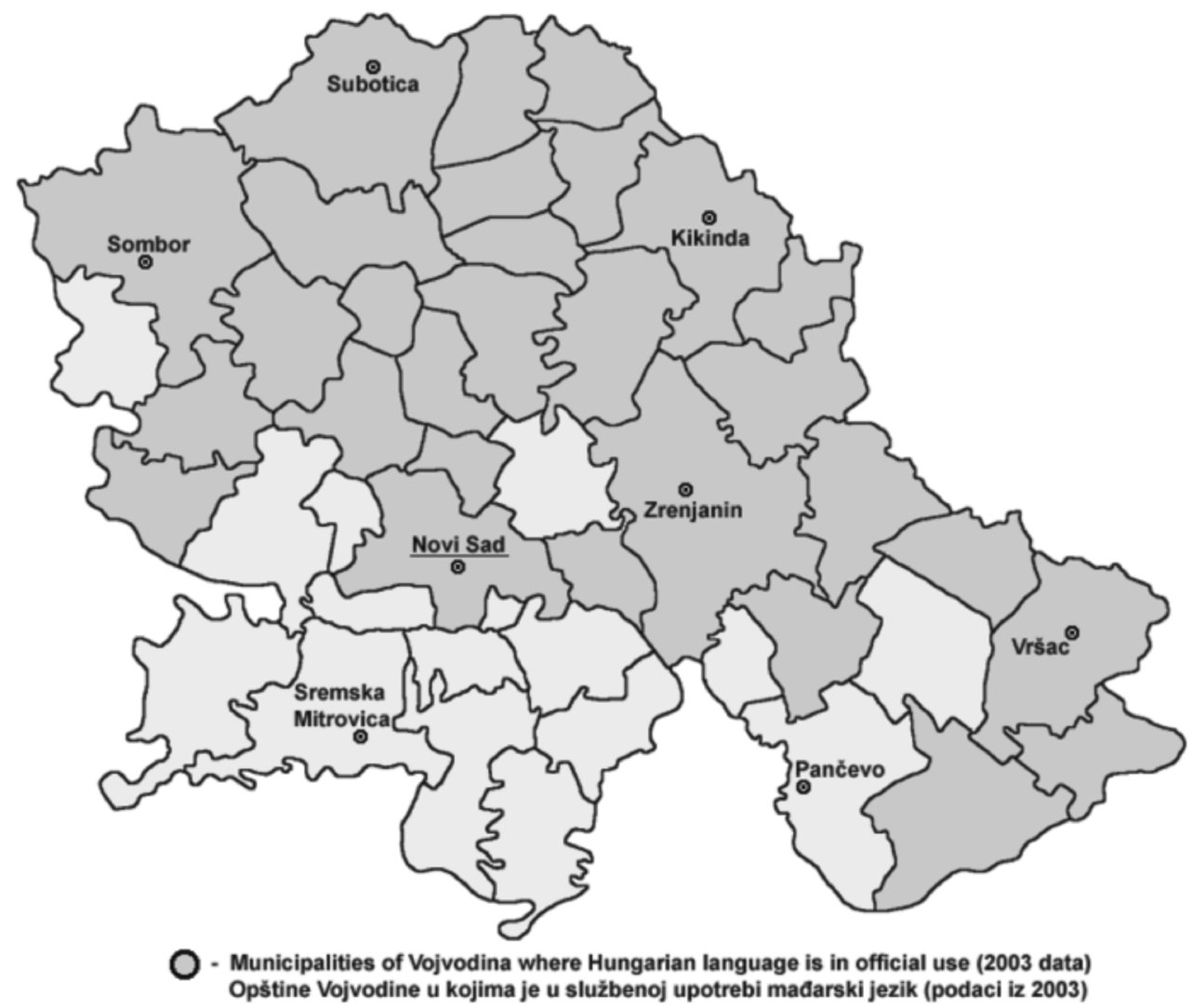

Picture 1. Vojvodina municipalities where Hungarian is in official use

Language loyalty among Hungarians is tightly interwoven with a sense of national belonging. According to the 2011 census, there is a high level of correspondence between ethnicity and mother tongue speakers among Hungarians, i.e. almost $96 \%$ of declared Hungarians gave Hungarian as their mother tongue. Our findings suggest that the status of Hungarian language in Serbia can be described as a satisfactory one. Namely, Hungarian and its script, as already mentioned, is one of the six official languages of Vojvodina, alongside Serbian, Croatian, Slovak, Ruthenian, and Romanian (STATUTE VOJ: Article 
26). More than $10 \%$ of the population in more than one third of all Vojvodina municipalities speaks Hungarian natively, whereas in half of all municipalities Hungarian native speakers represent at least $5 \%$ of the population (Đurić et al. 2014: 173). In more than 31 towns and municipalities, Hungarian is in official use, which makes around $65 \%$ of all Vojvodina municipalities. The picture below illustrates the official data from 2003, when Hungarian was in official use in 29 municipalities. ${ }^{12}$

\subsection{Institutional Support}

Hungarians in Vojvodina are institutionally and culturally a very well organized minority. They are politically organized into several minority parties, among which the Alliance of Vojvodina Hungarians is the biggest and the most influential one. ${ }^{13}$

Hungarian as a language of instruction is used at all levels of education. In the Province of Vojvodina, 79 primary and 37 secondary schools offer complete education in Hungarian. Overall, 18,857 children attend primary and secondary schooling in Hungarian, as illustrated in the following table.

Table 2. Complete education in Hungarian (Report 2016)

\begin{tabular}{lccc}
\hline & Number of schools & Number of classes & Number of pupils \\
\hline Primary schools & 79 & $1,252+153$ mixed classes & 13,346 \\
\hline $\begin{array}{l}\text { Secondary schools - } \\
\text { Gymnasium, vocational and } \\
\text { technical schools }\end{array}$ & 37 & $262+37$ mixed classes & 5,511 \\
\hline
\end{tabular}

In addition, Hungarian is taught as an optional subject, Hungarian with Elements of National Culture, in 79 primary schools, whereby 2,978 pupils are instructed in this subject. (Report 2016)

Hungarian is also a language of instruction at some faculties in Vojvodina: Department for Hungarian Studies at the Philosophical Faculty of the University

12 Provincial Secretariat Republic of Serbia. Autonomous Province of Vojvodina. Provincial Secretariat for Education, Regulations, Administration and National Minorities - National Communities. Available at: http://www.puma.vojvodina.gov.rs/dokumenti/ostalo/sljezik.pdf last time visited on: 30 December 2016.

13 For the party's name in Hungarian and the website, see: Alliance of Vojvodina Hungarians (in Hungarian: Vajdasági Magyar Szövetség - http://www.vmsz.org.rs/sr). Other large Hungarian political parties in Serbia are: Democratic Community of Vojvodina Hungarians (in Hungarian: Vajdasági Magyarok Demokratikus Közössége - http://www.vmdk.org.rs/sajtovisszhang), Civic Alliance of Hungarians (in Hungarian: Magyar Polgári Szövetség - http://www.mpsz.net), Democratic Party of Vojvodina Hungarians (in Hungarian: Vajdasági Magyar Demokrata Párt - http://www.vmdp.freewebspace.com), The Movement of Hungarian Hope (in Hungarian: Magyar Remény Mozgalom - http://www.mrm.rs), and The Party of Hungarian Unity (in Hungarian: Magyar Egység Párt - http://www.mep.org.rs/index.php/hu) - last time visited on: 30 December 2016. 
of Novi Sad and Hungarian-Language Teacher Training Faculty of the University of Novi Sad, which are located in Subotica. ${ }^{14}$

One of the most important institutions is the Institute for the Culture of Vojvodina Hungarians in Senta. Besides, there are many theatres with performances in the Hungarian language: The Novi Sad Theatre, The Hungarian Drama in the National Theatre in Subotica, The Hungarian City Theatre 'Dezső Kosztolányi' in Subotica, The Chamber Stage in Senta, The Travelling Ensemble 'Tanyaszínház', etc. ${ }^{15}$

On its Channel 2 (RTV 2), Radio Television of Vojvodina, the public broadcaster in the province, broadcasts programmes in 9 minority languages, alongside Serbian: Hungarian, Slovak, Ruthenian, Romanian, Bunyev, Ukrainian, Romani, Croatian, and Macedonian. The TV programme in Hungarian, however, is the most represented one among minority languages, with 12 hours and 50 minutes a week of the original RTV 2 production and a total of 42 hours a week, which includes the original production, other TV productions, and reprises. There is also the private Pannon Radio and Television Programme from Subotica, with full-day programmes in Hungarian, and some other private local stations. ${ }^{16}$ Hungarian speakers regularly follow, via satellite and cable TV, channels from Hungary. Radio Novi Sad 2 (RTV2), the Vojvodina Radio, and the Catholic-Church-run Radio Maria broadcast fullday radio programmes in Hungarian; additionally, almost every settlement with significant numbers of Hungarians has a local radio station, e.g. Szabadkai Magyar Rádió (RTV Pannon, Subotica), Rádió Régió (Bačka Topola), etc. ${ }^{17}$

14 For the names in Hungarian and the websites, see: Department for Hungarian Studies at the Philosophical Faculty of the University of Novi Sad (in Hungarian: Újvidéki Egyetem BTK, Magyar Nyelv és Irodalom Tanszék - http://www.ujvidekimagyartanszek.ff.uns. ac.rs), Hungarian-Language Teacher Training Faculty of the University of Novi Sad (in Hungarian: Újvidéki Egyetem Magyar Tannyelvú Tanítóképző Kar - http://www.magister.uns.ac.rs) - last time visited on: 7 February 2017.

15 For the names in Hungarian and the websites, see: Institute for the Culture of Vojvodina Hungarians in Senta (in Hungarian: Vajdasági Magyar Múvelődési Intézet - www.vmmi.org), The Novi Sad Theatre (in Hungarian: Újvidéki Színház - http://www.uvszinhaz.com/?lang=hu), The Hungarian Drama in the National Theatre in Subotica (in Hungarian: Szabadkai Népszínház Magyar Társulat - http://www.szabadkaiszinhaz.com), The Hungarian City Theatre 'Dezső Kosztolányi’ in Subotica (in Hungarian: Kosztolányi Dezső Színház - http://www.kosztolanyi. org), The Chamber Stage in Senta (in Hungarian: Zentai Magyar Kamaraszínház - https:// www.facebook.com/Zentai-Magyar-Kamarasz\%C3\% ADnh\%C3\%A1z-511139032267680/ about/), The Travelling Ensemble Tanyaszínház (in Hungarian: Tanyaszínház - http://www. tanyaszinhaz.com/magunkrol.html) - last time visited on: 7 February 2017.

16 For the names in Hungarian and the websites, see: Radio Television of Vojvodina 2 (in Hungarian: Vajdasági Rádió és Televizió - http://www.rtv.rs/sr_lat/program/drugi-program), Pannon RTV (http://pannonrtv.com/web2) - last time visited on: 7 February 2017.

17 For the names in Hungarian and the websites, see: Radio Novi Sad 2 (in Hungarian: RTV Újvidéki Rádió 2 - http://radiomap.eu/rs/play/novi-sad-2), Hungarian Vojvodina Radio (in Hungarian: Vajdasági Magyar Rádió - http://vajdasagradio.info), Radio Maria (in Hungarian: Mária Rádió - http://www.mariaradio.rs), Szabadkai Magyar Rádió (http://www.szbadkairadio.com), Rádió Régió (http://regioradio.co.rs); last time visited on: 7 February 2017. 
Hungarians have Magyar Szó, a daily paper published in Hungarian. There are also other newspapers and magazines published in Hungarian, e.g. Hét Nap (weekly), Képes Ifjúság (weekly - a journal for teenagers published by Magyar Szó), Jó Pajtás (weekly - a journal for children), Temerini Újság (weekly - a local paper of Temerin), Vajdaság Portál (Vojvodina portal), Dél Hír (Internet news portal), Napló (informative and cultural magazine), Pres Szó (web portal), Autonómia - A vajdasági civil portál (Vojvodina portal for civil society), Szabad Magyar Szó (web news portal), Vajdaság Ma (informative portal), Hungarológiai Közlemények (journal for Hungarian language, literature, and folklore published by the Department of Hungarian Language), Híd Kör (monthly - Vojvodina Hungarian literature, art, and social science journal), etc. ${ }^{18}$ In addition to current publications, there were also very influential journals for literature, art, and social criticism that played an important role in the Hungarian culture of Vojvodina, but these are currently no longer being published, e.g. Üzenet (quarterly - magazine for literature, art, social criticism, and social sciences; last issue in 2006), zEtna Magazin a vulkán alatt (monthly - web magazine and reading room; last issue in 2012), Létünk (quarterly - a journal for social, scientific, and cultural issues; last issue in 2015), Ex Symposion (quarterly - a journal for literature, art, philosophy, and social criticism; last issue in 2016), Családi Kör (weekly - family journal; last issue in 2016), DNS (magazine for culture; published by the Hungarian scientific conference of Vojvodina students), etc. ${ }^{19}$

Vojvodina Hungarians also have several publishing houses such as: Forum Publishing House, which publishes books mainly in Hungarian by Hungarian authors from Vojvodina; the publisher zEtna, founded by the zEtna magazine, publishes books in Hungarian and Serbian. It has also organized the Literary Festival in Senta since 2004. ${ }^{20}$ It is also noteworthy to mention Dombos Fest,

18 For the websites, see: Magyar Szó (http://www.magyarszo.rs), Hét Nap (http://hetnap.rs); Képes Ifjúság (http://www.kepesifi.com), Jó Pajtás (http://www.jopajtas.com), Temerini Újság (http://temeriniujsag.info/fooldal), Vajdaság Portál (http://www.vajdasag.eu), Dél Hír (http:// delhir.info), Napló (http://naplo.org), Pres Szó (http://www.press-szo.com), Autonómia - A vajdasági civil portál (http://hu.autonomija.info), Szabad Magyar Szó (http://szabadmagyarszo. com), Vajdaság Ma (http://www.vajma.info), Hungarológiai Közlemények (http:// ujvidekimagyartanszek.ff.uns.ac.rs/index.php/kiadvanyaink/hungarologiai-kozlemenyek), Híd Kör (http://www.hid.rs/hidkor.php); last time visited on: 7 February 2017.

19 For the websites, see: Üzenet (http://www.zetna.org/uzenet.html), zEtna (http://www.zetna. org), Létünk (http://www.letunk.rs), Ex Symposion (http://exsymposion.hu), Családi Kör (http://www.csaladikor.com), DNS (http://dns-online.hu). The New Symposium, a literary and art magazine, was especially influential and respectable among the Hungarian intellectual elite: it was founded in 1965 and was published until 1992, when the Yugoslav wars broke out. In 1993, the journal Ex Symposion, which continues the legacy of the New Symposium, was founded in Veszprém.

20 For the websites, see: Forum (Hun. Forum Könyvkiadó; http://www.forumliber.rs); Zetna Literary Festival (A zEtna (Minden) Irodalmi Fesztiválja - http://www.zetna.org/zek/folyoiratok/87/0/ index.html). 
which has been organized since 2001 in Mali Iđoš (in Hungarian: Kishegyes). Being very innovative and popular among a young audience, it has become an important musical landmark and symbol of identity and alternative Hungarian culture in Vojvodina. ${ }^{21}$

\section{Hungarian Speakers in Belgrade}

Although the province of Vojvodina is commonly considered to be the genuine cultural centre of Serbian Hungarians, Belgrade (in Hungarian: Belgrád, and historically Nándorfehérvár) also has a long tradition of Hungarian presence. Bolyai Society, functioning as a cultural centre, was active between the two world wars. The Hungarian Cultural Society of Belgrade was founded in 1940 and played an important role until 1956, when it was closed due to the consequences of political events in Hungary.

According to the censuses of 1921-1991, the number of Belgrade residents who claimed Hungarian nationality or native language did not vary considerably: it was never below 1,500 but never exceeded 6,000 residents. ${ }^{22}$ The last population census, held in 2011, gives the following figures: 1,659,440 inhabitants are registered in the city of Belgrade, with Belgrade appearing to be an exceptionally monolingual city with $94.8 \%$ of Serbian native speakers (2011 census). However, the census-taking practices should be considered in terms of what Foucault (1994) conceives of as a 'technology of power' that not only records but also contributes to creating identities by providing categories for enumeration. Thus, it may be inferred that the number of Belgrade minority members and Serbian non-native speakers is far greater than estimated. Data from the 2002 and 2011 censuses show that the number of individuals claiming Hungarian ethnicity as well as the number of Hungarian native speakers declined by $18 \%$ (language speakers) and $13 \%$ (ethnicity) within a span of 10 years, which is following the declining demographic trend of the entire Hungarian population in Serbia (cf. censuses of 2002, 2011) - cf. Table 3.

21 For the website, see: Dombos Fest (http://www.dombosfest.org); last time visited on: 8 February 2017.

22 Data collected by the censuses show the following figures related to the Hungarians in Belgrade: in 1921 - 1,478 (native speakers - NS); in 1931 - 5,792 (NS); in $1948-3,427$ (nationality - N); in $1953-3,817(\mathrm{~N})$; in $1961-5,043(\mathrm{~N})$; in $1971-4,511(\mathrm{~N})$; in $1981-3,297(\mathrm{~N})$; in $1991-2,402$ (N) (cf. population censuses of 1921-1991). All relevant census data can be obtained at the Archive of the Statistical Office of the Republic of Serbia (http://webrzs.stat.gov.rs/WebSite). 
Table 3. Population census: native speakers of Hungarian and ethnic Hungarians in Belgrade (population censuses of 2002, 2011)

\begin{tabular}{lcc}
\hline $\begin{array}{c}\text { Population Census } \\
\text { in Serbia }\end{array}$ & $\begin{array}{c}\text { Respondents with Hungarian } \\
\text { as 'mother tongue' }\end{array}$ & $\begin{array}{c}\text { Respondents with Hungarian } \\
\text { ethnicity }\end{array}$ \\
\hline Census 2002 & 1,604 & 2,080 \\
\hline Census 2011 & 1,330 & 1,810 \\
\hline
\end{tabular}

In Belgrade, there have been no Hungarian or bilingual (Serbian-Hungarian) kindergartens, primary, or secondary schools up to now. Nevertheless, Hungarian can be studied at the university level, at the Department of Hungarian Language and Literature, Faculty of Phililogy, University of Belgrade. ${ }^{23}$

In 2002, 'The Club of Hungarians in Belgrade - The Hungarian Society for the Cultivation of Culture' was founded by the Federal Ministry of Justice; but the society is no longer active. In addition, the Jesuit church of St. Peter in downtown Belgrade brings together believers every Thursday with masses held in Hungarian..$^{24}$ The church now has a library with a collection of 750 religious books in Hungarian - the legacy of Father Lórant Kilbertus and Father Imre Polgár. The collection is being renewed by Enikő Varga's donation. The library receives current journals and magazines in Hungarian, such as Vetés és Aratás and Hitélet, on a regular basis. Another place where Hungarians meet regularly is the Belgrade centre of the main Hungarian political party, Alliance of Vojvodina Hungarians; its Belgrade centre was founded in 2011. It organizes Hungarian language courses and cultural gatherings: lectures, promotions, exhibitions, parties, etc. ${ }^{25}$ In 2011, Hungarikum centar, a supermarket shop specialized in selling consumer products from Hungary, opened in Belgrade. Aside from commercial activities, it also organizes various cultural events with the Hungarian Embassy and provides basic tourist information about Hungary. ${ }^{26}$

Since 2014, the life of Hungarians in Belgrade has drastically changed. When Collegium Hungaricum was founded, it had a special status among other

23 The Department was founded upon the initiative of Professor Sava Babić, fairly late (1994) compared to the university tradition of Hungarian Studies in Vojvodina.

24 Belgrade and this church have a long history of Jesuit tradition and Hungarian language use for religious, educational, and preaching purposes. Jesuits came to Belgrade in the early $17^{\text {th }}$ century, and they used Hungarian from the very beginning. The first Jesuit church was built in 1732, and Hungarian language was, alongside German and Croatian, actively used in religious sermons in the first half of the $18^{\text {th }}$ century. By the $19^{\text {th }}$ century, there were no Jesuits residing in Belgrade, but they came back in 1929. In the following years, the parish was formed (cf. Cetinić et al. (ed.) 1981). During the 1990s, there were classes in Hungarian held in the church by theologian Enikő Varga.

25 Cf. The Alliance of Vojvodina Hungarians (in Hungarian: Vajdasági Magyar Szövetség; Srb. Savez vojvođanskih Mađara) (http://www.vmsz.org.rs/szervezet/belgradi-varosi-szervezet; https://www.facebook.com/SVM. Beograd); last time visited on: 11 February 2017.

26 Cf. Hungarikum centar (http://www.hungarikumcentar.rs); last time visited on: 11 February 2017. 
Hungarian cultural institutions which were part of the Balassi Institute Network (in Hungarian: Balassi Intézet). ${ }^{27}$ In other words, Collegium Hungaricum serves as 'a strategic bastion for Hungary's presence in international research and science'. ${ }^{28}$ There are only six Collegium Hungarica worldwide: in Vienna, Berlin, Paris, Rome, Moscow, and Belgrade. Thus, the official Hungarian cultural policy recognizes Belgrade as a strategically very important centre. The Institution is located in the heart of Belgrade and has significant cultural activities. It organizes lectures, exhibitions, literary and artistic gatherings, concerts, debates, etc. All activities are in Hungarian; Serbian is only used as a second language. It has therefore become a crucial gathering place not only for Hungarian-language speakers living in Belgrade and its neighbourhoods but also for all those who are interested in Hungarian culture.

The Hungarian speakers in Belgrade regularly follow Radio Television of Vojvodina II and satellite programmes from Hungary. The younger speakers are following Hungarian websites on the Internet. At the annual Belgrade International Book Fair, Hungarian books are exhibited on the stand of National Minorities and The Hungarian Publishers Association, where presentations and lectures are held in Hungarian.

In our paper, Balla et al. 2012, we argued that Hungarians in Belgrade did not create any solid speech community until 2012; they were rather individuated persons who gathered in small family circles, at church, or at university. Nevertheless, after Collegium Hungaricum was founded, the use of Hungarian language and the state of the Hungarian community in Belgrade has significantly changed. We can now speak of the loosely structured community of the Belgrade Hungarians.

\subsection{Survey on Hungarian Language Use in Belgrade}

Research on the Hungarian language use in Belgrade was carried out by the Institute of Balkan Studies SASA and the Faculty of Philology, University of Belgrade. The survey was based upon questionnaires, which were disseminated among the Hungarian-speaking population in Belgrade, e.g. students of Hungarian,

27 The Balassi Institute's (in Hungarian: Balassi Intézet) programmatic aim is to spread and promote Hungarian culture abroad and to introduce the traditions and cultures preserved by Hungarians to other cultures. It has a network of 23 cultural institutions located in 21 countries as well as three cultural diplomats. The goal of Hungarian institutes abroad is to promote and support Hungary's cultural heritage, the encouragement of international cooperation in culture and science, the furthering of Hungarian-language education and the introduction of Hungary's culture and society to foreign audiences by means of various programmes (http://www.balassiintezet.hu/ en/balassi-institute-hq; https://www.facebook.com/collegiumhungaricumbelgrad); last time visited on: 11 February 2017.

28 Cf. The Balassi Institute (in Hungarian: Balassi Intézet) (http://www.balassiintezet.hu/en/ balassi-institute-hq); last time visited on: 11 February 2017. 
Hungarian natives, and citizens who, due to various reasons, happened to know and use at least some Hungarian. We used a quantitative approach to database analysis, employing sociolinguistics in its basic form, which implies a correlation of the language parameters with the social ones in order to identify the social context in which they appear (Filipović 2009: 24).

The questionnaire was modelled after others used in the sociolinguistic research focusing on Hungarian-speaking communities (cf. Gal 1979, Wasserscheidt 2010). It is divided into three sections:

A. domains of language use - questions on the language use across various domains,

B. communication - questions on the language use in different communicative settings, and

C. attitudes - questions on the attitudes on language use.

Respondents were offered to choose between two questionnaires, one in Serbian and one in Hungarian. The survey was voluntary and anonymous, and the respondents were asked to give only personal data necessary for statistical purposes, such as age, gender, education, place of childhood and pre-university schooling, and place of residence. In addition to the survey questionnaires, we also used the method of participant observation in order to complement our data.

\subsection{Survey Results: Respondents' Stratification and the Domains of Language Use}

Sixty respondents have filled out the questionnaires so far; 35 in Serbian and 25 in Hungarian. The respondents' personal data show that they make up a very heterogeneous group: 34 of the respondents were women, compared to 26 men; the respondents' ages ranged from 18 to 77 . Regarding education, there were around $80 \%$ with either a junior college degree or a university diploma, and $20 \%$ had a high school diploma. ${ }^{29}$ The majority of the respondents grew up either in Vojvodina $(55 \%)$ or in Belgrade (30\%), finished school and university in Belgrade, and work and live in Belgrade permanently. The questionnaires do not allow us to draw any conclusion about the ethnic composition of the families. Participant observation, however, suggests that Hungarian-speaking respondents who come from Vojvodina are more likely to originate from endogamous marriages, while respondents who grew up in Belgrade are more likely to be from exogamous marriages. According to our survey, the majority learnt Hungarian either during childhood - i.e. Hungarian native speakers - or at the university - i.e. Serbian native speakers.

The survey results and the participant observation also show that Hungarian is actively used in the domains in which its use is institutionalized: the Department

29 Junior college (in Serbian: 'viša škola') is a type of lower university education that lasts for two years. 
of Hungarian Language and Literature, the Catholic church of St. Peter, the Belgrade centre of the political party Alliance of Vojvodina Hungarians, the Hungarian Embassy, and Collegium Hungaricum. However, due to the very small number of speakers, Hungarian is almost never or very rarely used in public services and in public places, e.g. in government offices, markets, or at a doctor (Balla et al. 2012).

\subsection{Hungarian Speakers in Belgrade and Language Rights Awareness}

A sociological survey which was carried out in 2002 among minority groups suggested that Hungarians in Serbia were poorly informed about their minority rights, which was a surprise in view of their long-standing presence and relatively high average educational level. According to the 2002 survey, few Hungarian respondents knew that inhabitants of municipalities constituting over $15 \%$ of population were entitled to use their mother tongue in communication with public services (19\%), to obtain public documents $(24 \%)$ and IDs $(25 \%)$, and to use their language in judicial and administrative proceedings (33\%) (cf. Briza et al. 2002: 105-114).

In our sociolinguistic survey (2012-2015), we also examined the level of language rights awareness among the Hungarian speakers in Belgrade. The question samples which relate directly or indirectly to language rights were the following:

6. I avoid using Hungarian in public:

$\square$ yes $\square$ no

If 'yes', why?

17. Which language do you use in your personal documents?

$\square$ Hungarian $\square$ Serbian $\square$ both languages

18. Do you know that you are legally entitled to:

- have your name and family name written in Serbian and Hungarian in your personal documents? $\square$ yes $\square$ no

- use Hungarian in city hall and court? $\square$ yes $\square$ no

It is important to emphasize that the majority feels free and relaxed (84\%) when using Hungarian in public. The respondents' comments show that if they avoid speaking Hungarian in public it is due to the fact that either they do not have anyone to talk to who comprehends Hungarian, or they do not yet speak it proficiently.

Our survey demonstrated that around $60 \%$ were familiar with the right to use Hungarian language in court and city hall: $52 \%$ of the respondents who filled in the questionnaires in Serbian language and $76 \%$ of those who filled them in in 
Hungarian. However, almost the same number of respondents were not aware of the right to use Hungarian language in the issuing of documents: more than half of the respondents who filled them in in Serbian and $47 \%$ of the respondents who filled the questionnaire in in Hungarian. Only $16 \%$ of the respondents use these language rights in the issuing of documents, i.e. $41 \%$ of those who filled the questionnaire in Hungarian; meaning that they have documents in two languages, Serbian and Hungarian. Comparing the results from the survey in 2002 and our survey from 2012-2015, it can be seen that the level of language rights awareness, although still not satisfactory, is on the rise among members of the Hungarian minority community.

\section{Conclusions}

Serbia, and especially its northern province, Vojvodina, adopted a series of very progressive laws for minority language protection and regulation of the minority language rights. However, as is the case with many countries, sometimes, the word of law does not correspond with practice. Thus, one challenge appears to be the lack of knowledge and information among members of the minority community. The other challenge we can find is in the sphere of the implementation of laws. Namely, sometimes the laws are hard to implement due to the lack of funding and skilled administration.

In the paper, we analysed the ethnolinguistic vitality of the Hungarian minority in Serbia and the language rights awareness. According to demographic indicators, status and institutional support, the Hungarian minority shows a rather complex picture. On the one hand, it can be described as a shrinking community, with very low birth rate and high emigration rate. According to the historical and language status and judging by the institutional support, it seems to be a vital and developed community. Although the Hungarians are concentrated in the Serbian northern province of Vojvodina, in this paper, we focused on the Hungarians of Belgrade. In our sociolinguistic survey conducted among the Hungarians of Belgrade, we came to the conclusion that awareness of language rights is not very high, although the Hungarians generally have strong historical and national awareness. Our survey showed that almost two-thirds of the respondents were familiar with their right to use Hungarian language in court and city hall. However, almost the same number of respondents were not familiar with the right to use Hungarian in issuing of documents, while less than $20 \%$ of the respondents actually use Hungarian in their personal documents.

We argue that the lack of knowledge about minority rights among the members of minority communities and the lack of support in their implementation contribute to the marginalization of the minorities. In countries which are still in 
some kind of transitional process - as is the case with Serbia -, the law adoption process thus should place a special emphasis on the law implementation and the general level of awareness among the population regarding these legislative measures.

\section{References}

ARRAIZA, José-María. 2015. Good Neighbourliness as a Limit to Extraterritorial Citizenship: The Case of Hungary and Slovakia. In: Kochenov, D.-Basheska, E. (eds), Good Neighbourliness in the European Legal Context. Leiden, Boston: Brill, Nijhoff. 114-135.

BALLA, Mónika-BULJANOVIĆ, Sandra-ILIĆ [Mandić], Marija. 2012. Domains of Hungarian Language Use in Belgrade. Jezikoslovlje 13(2): 565-583.

BERETKA, Katinka. 2014. Fragile Autonomy Arrangements in the Republic of Serbia: The Traditional Autonomy of Vojvodina and the National Minority Councils. In: Salat, L.-Constantin, S.-Osipov, A.-Székely, I. (eds), Autonomy Arrangements around the World: a Collection of Well and Lesser Known Cases. Cluj-Napoca. 247-274.

BRIZA, Jan et al. 2002. Helsinki Files: National Minorities and Law. Belgrade: Helsinki Committee for Human Rights in Serbia and Humanitarian Centre for Integration and Tolerance.

BLOKKER, Paul-Kovács, Kriszta. 2013. Unilateral Expansionism: Hungarian Citizenship and Franchise Politics and Their Effects on the HungarianRomanian Relations. In: Kochenov, D.-Basheska, E. (eds), Good Neighbourliness in the European Legal Context. Leiden, Boston: Brill, Nijhoff. 136-159.

BRUBAKER, Rogers-FEISCHMIDT, Margit-FOX, Jon-GRANCEA, Liana. 2006. Nationalist Politics and Everyday Ethnicity in a Transylvanian Town. Princeton: Princeton University Press.

CETINIĆ, Srećko et al. (eds). 1981. Jubilej crkve Sv. Petra apostola u Beogradu. Blagovest - Prilog - Jubileji br. 1. Belgrade.

CSERGŐ, Zsuzsa-GOLDGEIER, James M. 2013. Kin-State Activism in Hungary, Romania, and Russia: the Politics of Ethnic Demography. In: Mabry, T. J.McGarry, J.-Moore, M.-O'Leary, B. (eds), Divided Nations and European Integration. University of Pennsylvania Press. 89-126.

CONST. Constitution of the Republic of Serbia (Serbian text: Ustav Republike Srbije - available at: https://www.constituteproject.org/constitution/ Serbia_2006.pdf?lang=en;

http://paragraf.rs/propisi_download/ustav_republike_srbije.pd; last time visited on 16 February 2017. 
ĐURIĆ, Vladimir-TANASKOVIĆ, Darko-VUKMIROVIĆ, Dragan-LAĐEVIĆ, Petar. 2014. Etnokonfesionalni i jezički mozaik Srbije. Belgrade: Republički zavod za statistiku.

FOUCAULT, Michel. 1994. Znanje i moć. Zagreb: Globus.

GAL, Susan. 1979. Language Shift: Social Determinants of Linguistic Change in Bilingual Austria. Academic Press INC.

GILES, Howard-BOURHIS, Richard-TAYLOR, Donald. 1977. Towards a Theory of Language in Ethnic Group Relations. In: Giles, Howard (ed.) Language, Ethnicity, and Intergroup Relations. New York: Academic Press.

GOJKOVIC, Nevena. 2009. System of Minorities' Protection in Serbia. Available at: http://www.kas.de/upload/auslandshomepages/serbien/Gojkovic_en.pdf; last time visited on: 16 February 2017.

HUNGARIAN Citizenship Act 2010. Act XLIV 2010 Amending Act LV 1993. Magyar Közlöny 2010/89 (in Hungarian: A magyar állampolgárságról szóló 1993. évi LV. törvény módosításáról).

ILIĆ [Mandić], Marija. 2014. Discourse and Ethnic Identity: The Case of the Serbs from Hungary. Munich-Berlin: Otto Sagner Verlag.

THE LAW 2010. Law on Official Use of Languages and Alphabets. The Official Gazette of the Republic of Serbia 101/2005, 30/2010 (in Serbian: Zakon o službenoj upotrebi jezika i pisma. Službeni glasnik republike Srbije 45/91, 53/93, 67/93, 48/94, 101/05, 30/10).

PETROVIĆ Tanja. 2009. Srbi u Beloj Krajini: Jezička ideologija u procesu zamene jezika. Belgrade: Balkanološki institut SANU, Založba ZRC.

POPULATION CENSUS 2002. Census of Population, Households and Dwellings in 2002. National Identity or Ethnicity. Data by Municipalities. Book 1. (Popis stanovništva, domaćinstva i stanova u 2002. Nacionalna ili etnička pripadnost. Podaci po opštinama). Belgrade: Republički zavod za statistiku, 2003.

2011. Census of Population, Households and Dwellings in the Republic of Serbia. Religion, Mother Tongue and Ethnicity. Data by Municipalities and Cities. Belgrade: Statistical Office of the Republic of Serbia, 2013.

POPULATION CENSUSES 1921-1991. Popisi stanovništva 1921. Opšta državna statistika. Beograd. 1923; Popisi stanovništva 1931. Opšta državna statistika. Belgrade. 1934; Popisi stanovništva 1948-1991, RZS. Belgrade.

RÁCZ, Krisztina. 2014. Vernacular Multiculturalism: Hungarian Youth in Vojvodina. In: Lisiak, A.-Smolenski, N. (eds), What Do Ideas Do? vol. 33. Vienna: IWM Junior Visiting Fellows' Conferences.

2017. Discourses and Practices of Multiculturalism: Hungarian Youth in Vojvodina and Prekmurje (Diskurzi in prakse multikulturalizma: madžarska mladina v Vojvodini in Prekmurju). Doctoral dissertation. Faculty of Social Sciences, University of Ljubljana. 
RATIFICATION of the Agreement 2004. The Law on the Ratification of Agreement between Serbia and Montenegro and the Republic of Hungary regarding the Protection of Minority Rights of the Hungarian National Minority Living in Serbia and Montenegro and the Serbian National Minority Living in the Republic of Hungary (Zakon o ratifikaciji sporazuma između Srbije i Crne Gore i Republike Mađarske o zaštiti prava mađarske nacionalne manjine koja živi u Srbiji i Crnoj Gori i srpske nacionalne manjine koja živi u Republici Mađarskoj). Available at: http://www.pravamanjina.rs/attachments/Zakon\%20o\%20 ratifikaciji\% 20sporazuma\% 20izmedju\% 20SCG\% 20i\%20R. \% 20Madjarske. pdf; last time visited on: 16 February 2017.

REPORT 2016. Report on the Implementation of the Action Plan for the Realization of the Rights of National Minorities (Izveštaj o primeni akcionog plana za ostvarivanje prava nacionalnih Manjina). The Office for Human and Minority Rights of the Government of the Republic of Serbia.

ROKAI, Petar-ĐERE, Zoltan-PAL, Tibor-KASAŠ Aleksandar. 2002. Istorija Mađara. Belgrade: Clio.

STATUTE VOJ. Statute of the Autonomous Province of Vojvodina (Statut autonomne pokrajine Vojvodine). Available at:

http://www.skupstinavojvodine.gov.rs/Strana.aspx?s=statut\&j=EN; Serbian text: http://www.skupstinavojvodine.gov.rs/Strana.aspx?s=statut; last time visited on: 16 February 2017.

THE RATIFICATION of ECRML 2005. Law on Ratification of the European Charter for Regional or Minority Languages. The Official Gazette of the Republic of Serbia 18/2005 (in Serbian: Zakon o ratifikaciji Evropske povelje o regionalnim ili manjinskim jezicima. Službeni glasnik republike Srbije 18/2005). Available at: http://www.pravamanjina.rs/attachments/Zakon\%20o\%20ratifikaciji\%20 evropske\%20povelje.pdf; last time visited on: 16 February 2017.

VUČKOVIĆ, Marija. 2004. Kajkavci u Banatu: lingvistička situacija i polna diferencijacija. In: Sikimić, B. (ed.), Skrivene manjine na Balkanu. Belgrade: Balkanološki institut SANU. 199-215.

WASSERSCHEIDT, Philipp. 2010. Mehrsprachigkeit und Sprachwandel bei Ungarischsprechern im serbischen Banat. In: Voss, Ch. (ed.), Ottoman and Habsburg Legacies in the Balkans: Language and Religion to the North and to the South of the Danube. Munich-Berlin: Verlag Otto Sagner. 197-246. 